\title{
A Study on the Chinese Enterprise Annuity Replacement Rate Problem
}

\author{
Mei YU \\ Research Center of Applied Finance, School of Finance and Banking, University of International \\ Business and Economics, Beijing 100029, China \\ E-mail: yumei@uibe.edu.cn \\ Haibin XIE \\ Research Center of Applied Finance, School of Finance and Banking, University of International \\ Business and Economics, Beijing 100029, China \\ E-mail: hbxie@amss.ac.cn \\ Xiaowei HUANG \\ Research Center of Applied Finance, School of Finance and Banking, University of International \\ Business and Economics, Beijing 100029, China \\ E-mail: kittyhuang@yeah.net \\ Jinhai XU \\ Research Center of Applied Finance, School of Finance and Banking, University of International \\ Business and Economics, Beijing 100029, China \\ E-mail: jinhaixu9003@gmail.com \\ Dan RALESCU \\ Department of Mathematical Sciences, University of Cincinnati, USA \\ E-mail:dan.ralescu@math.uc.edu
}

\begin{abstract}
In this paper, the enterprise annuity replacement rate in China is discussed. The enterprise annuity replacement rate refers to the ratio of pension income and wages income before retired. It is an important indicator to measure the standard of living of the elderly population. The paper succeeded derived the equilibrium model of the enterprise annuity fund under the cost and management fee, and the enterprise annuity replacement rate is deduced. Moreover, the sensitivity analysis of each parameter is given, and the enterprise annuity rate of substitution for different gender is also obtained, which shows that the existing system of enterprise annuity unfairness to exist between men and women.
\end{abstract}

Keywords enterprise annuity; cost and management fee; substitution rate; gender difference

Received November 15, 2013, accepted January 3, 2014

Supported by NSFC (Grant No. 70901019); the National Social Science Fund Project (Grant No. 12CGJ027); the Foundation of UIBE (Project No. 12QD07) 


\section{Introduction}

China is a country with a high speed of economic development and a very large amount of people. Since the Reform and Opening Policy, the average life expectancy has substantially increased together with the development of the society and the economy. According to China National Bureau of Statistics, the ratio of population aged 65 and over to total population has increased by $1.91 \%$ than a decade ago. Due to the strict Family Planning Program in China, the low fertility rate will lead to more aging population and serious long-term aging. The aging of the population will trigger all kinds of conflicts and problems in society, on top of which is the deterioration of the living standard of the elderly people. To build a sound social security system is a pressing issue that relates to the stability of Chinese society and the life quality of ordinary people.

The reform of the pension scheme in China has experienced three stages. The first stage is the traditional system before the third plenary session of the twelfth central committee in 1984. The second stage is the social pooling and pilot as a whole in the late 1980s, and last stage is the stage of "combining social pooling with personal accounts" since 1995. As a component of social security system, enterprise annuity was firstly proposed in the "About the Enterprise Employees' Pension System Reform Decision" issued by the State Council in 1991. The decision for the first time pointed out that "The State advocates and encourages enterprises to implement the supplementary pension insurance". Two laws and regulations implemented in 2004 concerning the enterprise annuity have indicated that the enterprise annuity scheme has gradually developed as the supplementary pension insurance of Chinese basic social pension insurance system. Statistically, the number of staffs participating the enterprises annuity has reached 15.77 million in 2011 and the enterprise annuity fund balance has amounted to 357 billion, which was an increase of 2.92 times compared with 2006. Although the scale of enterprise annuity grows smoothly overall, its absolute scale is far less than that of the basic pension insurance, which, as a whole, is still in the dominant position. However, with the development and improvement of Chinese pension scheme, enterprise annuity will finally become a crucial component of the social security system. Thus, the research about Chinese pension scheme has aroused the attention of local government and general scholars.

Since 1875, the world's first formal enterprise annuity program established in America. The enterprise annuity program has been widely accepted and rapidly developed in the world because of its own merits and the low substitution rate of the public annuity. When it comes to analysis, as being a part of the pension scheme, enterprise annuity is always incorporated into the overall framework of the pension scheme. The classic model about the enterprise annuity is the Iteration Model (see [1], [2]), based on which Diamond and Mirrlees constructed the social insurance model about random retirement ([3]), showing that the accumulated contribution is inversely proportional to the participation age in the pension, while the annuity income is directly proportional to the retirement age. Reference [4] indicated that the essence of the pension insurance is a kind of deferred life annuity and the actuarial present value of the benefits is equal to the actuarial final value of the contributions. Then some scholars constructed the

Enterprise Annuity Fund Balance Model, empirically analyzed and measured the enterprise annuitys substitution rate(see [5], [6]) and found out that the excessive expectation towards the 
substitution rate will lead to the decline of working willingness of the elderly workers (see [7]).

Among the analysis about the main factors influencing the substitution rate of enterprise annuity such as annuity investment income and asset allocation, Reference [8] indicated that both the present value of the payment at now and that of the payment in the future should be determined before the decision of payment amount and he also thought that the risk refers to the degree of change between the payment and the annuity itself. [9] considered that the traditional defined benefit pension management only focused on policies that concerned assets, which led to the present value of payment succeeding what it should have been. By using the Option Pricing Theory, [10] has built models to study the increase of pension insurance. [11] has found out that the return rate is the stability of the pension system under the random condition, and [12] has studied the best investment method.

In recent years, many learners have discussed the pension issue in different countries. [13] analyzed the European pension system in detail. [14] studied the pension issue in China. [15] researched the pension system in Poland and Hungary, two major counties in middle Europe. [16] empirically analyzed the pension system in Japan. [17] studied the service types and expenses of pension management in various countries. Besides, other problems about pension system have drawn the attention of many professors. [18] discussed the government's designation of framework of pension system. [19] analyzed how the pension system had influenced the company's capital structure. [20] discussed the advantages and disadvantages of pension system. [21] empirically analyzed the capital cost of enterprise pension plan and financial constraints. [22] used the Life Cycle Model to research the assets allocation and contribution period of the pension. [23] analyzed the influence of pension system towards companies and finance.

From above we may conclude that although the present documents have achieved the academic goals to some degree, researches concerning enterprise annuity plan in China are relatively rare. This essay mainly researches the substitution rate of Chinese enterprise annuity and uses the Actuarial Principles to build the modified enterprise annuity fund balance model under the consideration of varies costs and expenses of enterprise annuity fund. Meanwhile, we discuss sensitivity of the substitution rate of enterprise annuity to some factor, and calculate the substitution rate of the enterprise annuity of different genders, and also put forward some practical references about the development and norms of current enterprise annuity system. What should be pay attention to is that because of the difficulties of quantifying the costs and expenses of the enterprise annuity which have always been ignored, the calculation results are often incorrect. The main contribution of this essay is the building of enterprise annuity fund balance model which included the variables such as costs and management expenses of enterprise annuity fund and the deduction of the substitution rate of enterprise annuity. Also, we calculate how the different genders with different participation ages have influenced the substitution rate of enterprise annuity.

The structure of this essay is as follows: in Section 2, we build the fund balance model of enterprise annuity, and deduce the substitution rate of enterprise annuity. Moreover, we make empirical analysis. In Section 3, we introduce the research about relationship between genders and substitution rate of Chinese enterprise annuity. In Section 4, we make conclusions and give suggestions to the regulation and development of the current enterprise annuity system. 


\section{Sensitivity analysis of substitution rate of Chinese enterprise annu- ity}

In this section, we will build the enterprise annuity fund balance model and deduce the substitution rate of enterprise annuity.

\subsection{Enterprise annuity fund balance model}

Before we deduce the model, we give some assumptions as following.

Assumption 1 The type of enterprise annuity is assumed to be defined contribution (DC) form.

Being compared with defined contribution pension, the defined benefit pension has the shortcomings of being complex to calculate, difficult to determine the amount of funding, and not conductive to the understanding of workers. Changping Wang (2005) concluded that enterprise annuity plan will be the main development trend of the DC type, in which companies have the right of investment and decision. In this paper, when building the model, a DC type, that is, a defined contribution form, is assumed in the model.

Assumption 2 The contributions are assumed to be paid annually.

This assumption means that employers and employees pay annuities monthly according to the amount of their salary. The annuity fund is managed through fund managers and fund custodians to increase the value of the fund and accumulate the operation incomes that will eventually become personal properties. For the sake of simple and convenient calculation, this paper assumes that contributions of personal accounts of the annuity fund are carried out on an annual basis and enterprises and workers both pay fees to the pension plan in accordance with a fixed percentage of workers annual income.

Assumption 3 Fixed annuity is assumed to be paid regularly in the payment period.

"Enterprise Annuity Pilot Scheme" states that "workers that have reached the mandatory retirement age can draw annuities once or regularly from personal enterprise annuity accounts". This paper assumes that the enterprise annuity payments in the payment period will be in the form of a fixed annuity.

Assumption 4 The enterprise annuity plan is assumed to be continued.

We know that it is not always for workers participating in the annuity plan from the beginning of their work to the date of retirement. Workers might leave in the mid way and interrupt the enterprise annuity plan for some reasons, under which situation the continuity of contributions of the enterprise annuity fund can not be guaranteed and the fund balance model is difficult to be set up. Thus this assumption ensures the successful construction of the enterprise annuity fund model.

Assumption 5 Enterprise annuity management cost is assumed to be properly quantified as a fixed percentage of annual income.

Previous models assumed that the variety of costs and expenses are ignored in the fiduciary management of the enterprise annuity fund. We know that the management costs and expenses mainly include the operating expenses and other costs due to the systematic risk or agency risk. Although ignoring the costs of annuity will simplify the model and facilitate the model calculation, the accuracy of the substitution rate will be affected. This paper assumes that 
the enterprise annuity management costs can be properly quantified, which means the total costs and expenses could form a fixed ratio to the annual wages of workers participating in the pension plan. Now we give the notations of model as follows:

$j$ : the initial age of workers participating the enterprise annuity plan.

$r$ : the retirement age of workers participating the enterprise annuity plan.

$i$ : the investment yield of enterprise annuity fund.

$d$ : the highest death age of workers participating the enterprise annuity plan.

$T$ : the discount factor, $T=\frac{1}{1+i}$.

$D$ : the fixed annuity the retired workers participating the plan will receive each year. The annuity comes from the accumulation of the enterprise annuity fund, which should be distinguished from the annual retirement pension.

$(F Y)_{j}$ : the income level of the enterprise employees at the age of $j$ when initially join the plan.

$(E Y)_{j+t}$ : the expected income level of the employees at the age of $j+t$, in which, $(E Y)_{j+t}=$ $(F Y)_{j}(1+g)^{t}$.

$g$ : the growth rate of employees' annual income.

$P_{j}^{t}$ : the probability of workers at the age of $j$ living until $j+t$.

$C$ : the contribution rate of workers participating the enterprise annuity plan. Specifically, it is the fixed proportion of the co-payment of the enterprises and workers at the end of each year to total income of workers in that year.

$R$ : the substitution rate of enterprise annuity. Substitution rate of enterprise annuity is always measured through the ratio of the annual fixed annuity received by the retired employees to their income level $(E Y)_{r-1}$ one the year before retirement age $(r-1)$ to reflect the degree of the living standard after retirement substituting for that before retirement.

\subsection{The enterprise annuity fund balance model}

According to the Actuarial Balance Theory in insurance, the final value of the contribution period should be equal to the present value of the payment period. Namely, employees participating the enterprise annuity plan pay a fixed percentage of charges of their annual income each year from their age of $j$ to the year before retirement age $(r-1)$. Those contributions can get appreciation through proper investment, and the accumulated final value of enterprise annuity at their age of $r-1,(P P C)_{r}$, is equal to the present value of annuity received each year after retirement discounted to the beginning of retirement age of $r,(P V D)_{r}$, which can be expressed through the equation:

$$
(P P C)_{r}=(P V D)_{r}
$$

The annual income of $j$-year-old employees after $t$ years entering the enterprise annuity is as follows:

$$
(E Y)_{j+t}=(F Y)_{j}(1+g)^{t}
$$

Then the contributions of employees in year $t$ is as follows:

$$
C(E Y)_{j+t}=C(F Y)_{j}(1+g)^{t}
$$


According to the assumption that enterprises and employees pay at the end of each year and the contribution period are $r-j$ years (employees made their first payment at the end of age $j$, and their last payment at the end of age $(r-1)$, thus the accumulated final value of enterprise annuity fund is as follows:

$$
\begin{aligned}
(P P C)_{r}= & C(F Y)_{j}(1+g)^{0}(1+i)^{r-j-1} P_{j}^{j+0}+C(F Y)_{j}(1+g)^{1}(1+i)^{r-j-2} P_{j}^{j+1}+\cdots \\
& +\cdots+C(F Y)_{j}(1+g)^{r-j-1} P_{j}^{r-1} \\
= & C(F Y)_{j} \sum_{k=0}^{r-j-1}(1+g)^{k}(1+i)^{r-j-k-1} P_{j}^{j+k}
\end{aligned}
$$

Assuming that employees get the annuity at the beginning of each year right after their retirement until death, then the receiving period should be $d-r$ years, so the right side of the equation (1) can be deduced as follows:

$$
(P V D)_{r}=D T^{0} P_{r}^{0}+D T^{1} P_{r}^{1}+\cdots+D T^{d-r-1} P_{r}^{d-r-1}=D \sum_{k=0}^{d-r-1} T^{k} P_{r}^{k}
$$

Through the simplification of equation (1), (4) and (5), it can be obtained as follows:

$$
C(F Y)_{j} \sum_{k=0}^{r-j-1}(1+g)^{k}(1+i)^{r-j-k-1} P_{j}^{k+j}=D \sum_{k=0}^{d-r-1} T^{k} P_{r}^{k}
$$

And the money that employees get every year after retirement is:

$$
D=\frac{C(F Y)_{j} \sum_{k=0}^{r-j-1}(1+g)^{k}(1+i)^{r-j-k-1} P_{j}^{k+j}}{\sum_{k=0}^{d-r-1} T^{k} P_{r}^{k}}
$$

The annual income one year before retirement is:

$$
(E Y)_{r-1}=(F Y)_{j}(1+g)^{r-j-1}
$$

The substitution rate of enterprise annuity is:

$$
R=\frac{D}{(E Y)_{r-1}}=\frac{C \sum_{k=0}^{r-j-1}(1+g)^{k}(1+i)^{r-j-k-1} P_{j}^{k+j}}{(1+g)^{r-j-1} \sum_{k=0}^{d-r-1} T^{k} P_{r}^{k}}
$$

The above all deduction about substitution rate of enterprise annuity is based on the situation that no costs and management expenses exist. However, according to the assumptions above, costs and expenses are the indispensable parts when calculating the substitution rate. We assume that the percentage of costs and expenses to the total contributions is $f(0 \leq f<1)$ then the model (9) can be modified. We can deduce the substitution rate of enterprise annuity that includes the costs and management expenses (10)

$$
\begin{aligned}
R & =\frac{D}{(E Y)_{r-1}} \\
& =\frac{C \sum_{k=0}^{r-j-1}(1+g)^{k}(1-f)(1+i)^{r-j-k-1} P_{j}^{k+j}}{(1+g)^{r-j-1} \sum_{k=0}^{d-r-1} T^{k} P_{r}^{k}}
\end{aligned}
$$

\subsection{The statement of parameters}

1) The starting age of workers participating in the enterprise annuity plan is set to be 18 years old, i.e., $j=18$. 
In accordance with the prediction about the average employment age of urban workers in China in 2001-2050 from "China's Social Insurance Pension Fund Calculation and Management", and the research group in Social Insurance Institute of the Chinese Ministry of Labor and Social Security, the average employment age is 18 after 2010. In addition, according to the argument from United Nations Development Programmer, the average years of education in China are 7.5. This paper applies this data and assumes that workers enter the enterprise annuity plan in the initial year of their employment, namely, $j=18$.

2) The average retirement age of workers is set to be 58 years old, i.e., $r=58$.

About the retirement age, Chinese law has already provided in the 1950s that the retirement age of enterprise employees should be 60 for male workers, 55 for female cadres and 50 for female workers. Such a provision was settled in the "Interim Provisions of the State Council on Workers and Staffs Retirement Processing" publicized in 1958, and has been in use ever since. But with the changes in the structure of Chinese society, many people predicted that China will gradually withdraw from the provision of retirement age, which, in fact, is an international trend. This paper does not consider the phenomenon of earlier retirement and approximately take the parameter $r$ as 58 years old in the enterprise annuity fund balance model, namely, $r=58$.

3) The growth rate of workers' annual revenue (nominal rate) is set to be $13.74 \%$, i.e., $g=13.74 \%$.

The nominal growth rate of workers' annual revenue can be estimated in the annually published "China Statistical Yearbook" by the State Bureau of Statistics (See Table 1). This

Table 1 Annual incomes and growth rates in urban areas in 1995-2011

\begin{tabular}{ccc}
\hline Year & Annual income & Nominal growth rate \\
\hline 1995 & 5348 & \\
1996 & 5980 & 0.11817502 \\
1997 & 6444 & 0.07759197 \\
1998 & 7446 & 0.15549348 \\
1999 & 8319 & 0.11724416 \\
2000 & 9333 & 0.12188965 \\
2001 & 10834 & 0.16082717 \\
2002 & 12373 & 0.1420528 \\
2003 & 13969 & 0.12899054 \\
2004 & 15920 & 0.1396664 \\
2005 & 18200 & 0.14321608 \\
2006 & 20856 & 0.14593407 \\
2007 & 24721 & 0.18531837 \\
2008 & 28898 & 0.16896566 \\
2009 & 32244 & 0.11578656 \\
2010 & 36539 & 0.13320308 \\
2011 & 41799 & 0.14395577 \\
\hline Average: & 17601.35294 & 0.137394424 \\
\hline
\end{tabular}

paper assumes that the growth rate of enterprise employees' annual revenue is $13.74 \%$, namely, $g=13.74 \%$.

4) The yield of enterprise annuity fund is set to be $8.87 \%$, i.e., $i=8.87 \%$. 
Chinese Ministry of Human Resources and Social Security has been counting the investment yield of enterprise annuity since 2007. After five years of statistics, except for the poor performance in 2008 and 2011, the other three years have achieved good return rates. In 2008, investment yield is $-0.83 \%$ and that in 2011 is $-0.78 \%$. But by now, from the overall situation, the investment yield is $8.87 \%$ on average. In 2004, the chapter 7 of the national publication, "Enterprise Annuity Fund Management Pilot Scheme", provides that the proportions of liquidity products and money market funds such as investment bank demand deposit, central bank bills, and short-term bond repurchase should not be less than $20 \%$ of the fund net assets; fixed income products and convertible bonds such as investment bank fixed deposits, negotiated deposits, treasury bonds, financial bonds and corporate bonds should not be more than $50 \%$ of the fund net assets. Among them, the proportion of government bonds should be no less than $20 \%$ of the fund net assets; investment in stocks and other equity products and insurance products should be no more than $30 \%$ of the fund net assets. Visibly, the government bond is one of the main investment targets for the enterprise annuity, which can effectively control risks, so it is reasonable to settle the investment yield of enterprise annuity fund as $8.87 \%$, namely, $i=8.87 \%$ and hence $T=0.9185$.

5) The contribution rate of enterprise annuity is set to be $16.67 \%$ of employees' average annual income, i.e., $C=16.67 \%$.

According to "Enterprise Annuity Trial Measures", enterprises and employees should pay for the annuity plan together. Enterprises pay no more than $1 / 12$ of the total wages of the company in previous years. The payment of enterprise and employees should not exceed the company's total annual wages in previous year by $1 / 6$. To facilitate calculation, this paper uses the upper limit of the joint contributions of employers and employees, that is, 1/6 of employees' average annual income. $C=16.67 \%$.

6) The costs and expenses of the enterprise annuity fund is set to be $2 \%$ of the employees' annual income, i.e., $f=2 \%$.

Part of the costs and expenses of the enterprise annuity fund were mentioned in the "Enterprise Annuity Fund Management Pilot Scheme", Chapter 8. The management fee that trustees get should not exceed $0.2 \%$ of the net assets of the enterprise annuity fund; the management fees that account managers receive monthly should not exceed 5 Yuan per account, and should be paid by enterprises separately; the custodian fees should not exceed $0.2 \%$ of the net asset of the fund; management fees that investment managers extracted should be no more than $1.2 \%$ of the net asset of the enterprise annuity fund. As is mentioned above, some of the costs and expenses of the enterprise annuity fund can not be quantified, which can only be estimated roughly. For the sake of calculation, this paper takes $2 \%$ as the costs and expenses rate of the enterprise annuity fund, namely $f=2 \%$.

7) Estimations about employees' survival probability and their age at death. We use the "China Life Insurance Mortality Table (2000-2003)" to measure the survival probabilities of workers, of which the highest death age was 105, that is, $d=105$. Survival probabilities are measured through the equation $P_{x}^{x+t}=\frac{l_{x+t}}{l_{x}}$ and $l_{x}$ can be derived from Table 2. 
Table 2 Chine life insurance mortality table (2000-2003)

\begin{tabular}{|c|c|c|c|c|c|c|c|}
\hline Age & $0.5 *(C L 3+C L 4)$ & Age & $0.5 *(C L 3+C L 4)$ & Age & $0.5 *(C L 3+C L 4)$ & Age & $0.5 *(C L 3+C L 4)$ \\
\hline 18 & 0.999671 & 40 & 0.999055 & 62 & 0.992962 & 84 & 0.926123 \\
\hline 19 & 0.999637 & 41 & 0.998985 & 63 & 0.992168 & 85 & 0.918136 \\
\hline 20 & 0.999607 & 42 & 0.998913 & 64 & 0.991284 & 86 & 0.909337 \\
\hline 21 & 0.999582 & 43 & 0.998839 & 65 & 0.990301 & 87 & 0.899656 \\
\hline 22 & 0.999563 & 44 & 0.99876 & 66 & 0.989182 & 88 & 0.889018 \\
\hline 23 & 0.999546 & 45 & 0.998672 & 67 & 0.987929 & 89 & 0.877347 \\
\hline 24 & 0.999532 & 46 & 0.99857 & 68 & 0.986532 & 90 & 0.864565 \\
\hline 25 & 0.99952 & 47 & 0.998466 & 69 & 0.984975 & 91 & 0.850595 \\
\hline 26 & 0.999508 & 48 & 0.99832 & 70 & 0.98324 & 92 & 0.835356 \\
\hline 27 & 0.999496 & 49 & 0.998152 & 71 & 0.981306 & 93 & 0.818777 \\
\hline 28 & 0.999482 & 50 & 0.997971 & 72 & 0.979151 & 94 & 0.800786 \\
\hline 29 & 0.999465 & 51 & 0.997786 & 73 & 0.976752 & 95 & 0.781321 \\
\hline 30 & 0.999445 & 52 & 0.997601 & 74 & 0.974118 & 96 & 0.760334 \\
\hline 31 & 0.999423 & 53 & 0.997404 & 75 & 0.97118 & 97 & 0.737789 \\
\hline 32 & 0.999398 & 54 & 0.997181 & 76 & 0.967966 & 98 & 0.71367 \\
\hline 33 & 0.999372 & 55 & 0.996922 & 77 & 0.964402 & 99 & 0.687989 \\
\hline 34 & 0.999343 & 56 & 0.996593 & 78 & 0.960451 & 100 & 0.660785 \\
\hline 35 & 0.999312 & 57 & 0.996173 & 79 & 0.956073 & 101 & 0.632133 \\
\hline 36 & 0.999276 & 58 & 0.995658 & 80 & 0.951224 & 102 & 0.602153 \\
\hline 37 & 0.999232 & 59 & 0.995073 & 81 & 0.945857 & 103 & 0.571006 \\
\hline 38 & 0.999181 & 60 & 0.99437 & 82 & 0.939922 & 104 & 0.538907 \\
\hline 39 & 0.999121 & 61 & 0.993676 & 83 & 0.933363 & 105 & 0 \\
\hline
\end{tabular}

Remark $1 C L 3$ refers to pension business table of men, and $C L 4$ refers to pension business table of women.

The parameters all above can be showed in the following Table 3, through which the substitution rate of Chinas enterprise annuity can be directly found out.

Table 3 Basic parameters in the enterprise annuity model

\begin{tabular}{cccccccc}
\hline Parameters & $j$ & $r$ & $g$ & $d$ & $i$ & $C$ & $f$ \\
\hline Numerical Value & 18 & 58 & $13.74 \%$ & 105 & $8.87 \%$ & $16.67 \%$ & $2 \%$ \\
\hline
\end{tabular}

\subsection{The empirical results and sensitivity analysis}

Substituting the settled parameters into the modified enterprise annuity fund model (10), we have:

$$
R=26.5574 \%
$$

Then we will make sensitivity analysis about the substitution rate of enterprise annuity, namely observing the change of substitution rate of enterprise annuity through the slight change 
of each variable. Since the China Life Insurance Mortality Table is still in the trial period and the highest survival probability and the age of death will not be much floating, this paper assumes that the value of these two parameters are fixed, and divides the remaining six parameters into two groups for the sensitive analysis. The details of operation are: keeping other parameters unchanged, calculate the change of substitution rate of enterprise annuity through a slight change in each parameter, and getting the degrees of influence that those parameters have on the living standard of retirees.

1) Sensitivity analysis of parameters $j$ and $r$.

Assuming other variables remaining constant, we analyze the changes in the substitution rate of enterprise annuity under the circumstances of the employees beginning age (in the enterprise annuity plan) being 1 year and 2 years earlier. The results can be reflected in Table 4 .

Table 4 Results of parameters sensitivity analysis (1)

\begin{tabular}{cccccc}
\hline$\Delta x$ & $R \%$ & $\Delta R(\%)$ & $\left|\frac{\Delta x}{x}\right|(\%)$ & $\frac{\Delta R}{R^{*}}(\%)$ & $\frac{\frac{\Delta R}{R^{*}}}{\frac{\Delta x}{x}}$ \\
\hline$\Delta j=-1$ & 29.5661 & 3.0087 & 5.5556 & 11.32905 & 2.039212 \\
$\Delta j=-2$ & 29.8186 & 3.2612 & 11.1111 & 12.27982 & 1.105185 \\
$\Delta j=-3$ & 27.2646 & 0.7072 & 1.7241 & 2.662911 & 1.544523 \\
$\Delta j=-4$ & 27.6114 & 1.054 & 3.4483 & 3.968762 & 1.150933 \\
\hline
\end{tabular}

From Table 4 , it can be easily found that the substitution rate of enterprise annuity $R$ is inversely proportional to $j$, which means that when decreases by one or two years, the substitution rate of enterprise annuity increases by three percentage points. Meanwhile, the retirement age $r$ is proportional to $R$, which means to postpone retirement can improve the substitution rate of enterprise annuity, however, the increase of $R$ is not much and also it is not easy to postpone retirement. From the elastic side, employees working in advance or deferring their retirement will both lead to the positive change of substitution rate of enterprise annuity, however, the more the years of work in advance or the more the years of postponing work, the less the elastic, indicating that its ability to improve the substitution rate of enterprise annuity is getting weaker. In comparison, if we do not take into account other factors, earlier work on the improvement of substitution rate of enterprise annuity is more pronounced than the postponement of retirement age.

2) Sensitivity analysis of parameters $g, i, c$ and $f$.

The parameters $j$ and $r$ are both expressed in ages, so this paper put them into one category when making the sensitivity analysis. The parameters $g, i, c$ and $f$, and are expressed in percentages, so this paper put them into the same group when doing the sensitivity analysis. Table 5 lists, respectively, that with one percent change of all the parameters, the changes of substitution rate of enterprise annuity and the corresponding values of elasticity.

Similarly, from Table 5 it can be found that the growth rate of employees' annual revenue, cost management fee rate $f$ of enterprise annuity fund are inversely proportional to $R$, while contribution rate $C$ and annuity yield $i$ are proportional to $R$. Among the four parameters, the substitution rate of enterprise annuity is the most sensitive one to changes in yield $i$, with one percent increase in $i, R$ increasing by at least 6 percent. The sensitivity of $f$ is also very strong and it is subject to relatively large impact of national policies, so it is necessary to reduce 
the management fees and costs of the enterprise annuity fund to avoid great decreases of the substitution rate of enterprise annuity.

Table 5 Results of parameters sensitivity analysis (2)

\begin{tabular}{cccccc}
\hline$\Delta x$ & $R \%$ & $\Delta R(\%)$ & $\left|\frac{\Delta x}{x}\right|(\%)$ & $\frac{\Delta R}{R^{*}}(\%)$ & $\frac{\frac{\Delta R}{R^{*}}}{x}$ \\
\hline$\Delta j=1$ & 23.65 & -2.9074 & 7.2780 & -10.9476 & -1.50421 \\
$\Delta i=1$ & 32.9847 & 6.4273 & 11.2740 & 24.20154 & 2.146669 \\
$\Delta C=1$ & 28.1505 & 1.5931 & 5.9988 & 5.998705 & 0.999984 \\
$\Delta f=1$ & 26.2864 & -0.271 & 0.5 & -1.02043 & -2.04086 \\
\hline
\end{tabular}

\section{The analysis of gender and substitution rate of Chinese enterprise annuity}

In Section 2, we regarded an employee as an universal individual when deducing the substitution rate of enterprise annuity, namely there is no gender distinction. However, in practical operation, there is a difference between male workers and female workers on the overall pension insurance replacement rate which is the same for substitution rate of enterprise annuity. The reason is that male workers retire relatively late. In accordance with Chinese law, the retirement age of male workers are at least five years later than female workers. From the empirical analysis in last chapter, we know that the later the retirement age, the higher the substitution rate of enterprise annuity; in addition, according to Pension Business Table of Men and Women, the survival probability for male and female workers who are of the same age is not the same, which also affects the substitution rate of enterprise annuity. Thus, this section makes the comparative analysis of substitution rate of enterprise annuity of male workers and female workers to calculate the differences and put forward some constructive ideas for the unfair enterprise annuity system caused by the gender factor.

We calculate the substitution rate of enterprise annuity for the male and female employees respectively. Since the current retirement age for male workers are 60 , the retirement age $R_{\text {male }}$ to calculate the substitution rate of enterprise annuity for men is assumed to be $60(r=60)$. We still assume that the starting age to work is 18 , namely $j=18$. The survival probabilities for male employees are shown in the following table:

Table 6 Survival probabilities for male employees

\begin{tabular}{cccccccc}
\hline Ages & $\begin{array}{c}P_{18}^{18+k} \\
(k=0, \cdots, 21)\end{array}$ & Ages $\begin{array}{c}P_{18}^{18+k}(k=22, \cdots, 41) \\
P_{60}^{60+k}(k=0,1)\end{array}$ & Ages & $\begin{array}{c}P_{60}^{60+k} \\
(k=2, \cdots, 23)\end{array}$ & Ages & $\begin{array}{c}P_{60}^{60+k} \\
(k=23, \cdots, 44)\end{array}$ \\
\hline 18 & 1 & 40 & 0.999171 & 62 & 0.998252 & 84 & 0.922565 \\
19 & 0.999949 & 41 & 0.99908 & 63 & 0.997293 & 85 & 0.913833 \\
20 & 0.999906 & 42 & 0.998985 & 64 & 0.996232 & 86 & 0.904261 \\
21 & 0.999871 & 43 & 0.998886 & 65 & 0.995054 & 87 & 0.893783 \\
22 & 0.999845 & 44 & 0.99878 & 66 & 0.993716 & 88 & 0.882331 \\
23 & 0.999823 & 45 & 0.998662 & 67 & 0.99223 & 89 & 0.869833 \\
24 & 0.999803 & 46 & 0.998527 & 68 & 0.990579 & 90 & 0.856221 \\
25 & 0.999786 & 47 & 0.99839 & 69 & 0.988746 & 91 & 0.841425 \\
26 & 0.99977 & 48 & 0.998207 & 70 & 0.986712 & 92 & 0.825377 \\
27 & 0.999753 & 49 & 0.997999 & 71 & 0.984455 & 93 & 0.808016 \\
28 & 0.999734 & 50 & 0.997779 & 72 & 0.981952 & 94 & 0.789288 \\
29 & 0.999712 & 51 & 0.997565 & 73 & 0.979175 & 95 & 0.769147 \\
\hline
\end{tabular}


Table 6 continued

\begin{tabular}{lccccccc}
\hline 30 & 0.999687 & 52 & 0.99736 & 74 & 0.976175 & 96 & 0.747559 \\
31 & 0.999658 & 53 & 0.997145 & 75 & 0.97286 & 97 & 0.724511 \\
32 & 0.999626 & 54 & 0.9969 & 76 & 0.969197 & 98 & 0.700005 \\
33 & 0.999591 & 55 & 0.996606 & 77 & 0.965151 & 99 & 0.674073 \\
34 & 0.999553 & 56 & 0.996237 & 78 & 0.960686 & 100 & 0.646774 \\
35 & 0.99951 & 57 & 0.995768 & 79 & 0.95576 & 101 & 0.618202 \\
36 & 0.999461 & 58 & 0.995169 & 80 & 0.95033 & 102 & 0.588487 \\
37 & 0.999403 & 59 & 0.994405 & 81 & 0.944347 & 103 & 0.557804 \\
38 & 0.999335 & 60 & 1 & 82 & 0.937763 & 104 & 0.526371 \\
39 & 0.999257 & 61 & 0.999116 & 83 & 0.93052 & 105 & 0 \\
\hline
\end{tabular}

Using formula (10), we can calculate the substitution rate of enterprise annuity for male employees is as follows:

$$
R_{\text {male }}=27.5422 \%
$$

Similarly, we can calculate the substitution rate of Chinese enterprise annuity for female employees. What differentiates is that we estimate that the retirement age for female employees is 53 , and their survival probabilities are shown in the following table:

Table 7 Survival probabilities for female employees

\begin{tabular}{cccccccc}
\hline Ages & $P_{18}^{18+k}$ & \multicolumn{2}{c}{$P_{18}^{18+k}(k=22, \cdots, 34)$} & & $P_{53}^{53+k}$ \\
& $(k=0, \cdots, 21)$ & Ages & $P_{53}^{53+k}(k=0, \cdots, 8)$ & Ages & $(k=9, \cdots, 30)$ & & $(k=31, \cdots, 52)$ \\
\hline 18 & 1 & 40 & 0.9995987 & 62 & 0.996535 & 84 & 0.937903 \\
19 & 0.999983 & 41 & 0.999549 & 63 & 0.995897 & 85 & 0.930588 \\
20 & 0.999967 & 42 & 0.999499 & 64 & 0.995183 & 86 & 0.922479 \\
21 & 0.999952 & 43 & 0.99945 & 65 & 0.994383 & 87 & 0.913504 \\
22 & 0.999939 & 44 & 0.999398 & 66 & 0.993473 & 88 & 0.903581 \\
23 & 0.999928 & 45 & 0.99934 & 67 & 0.992441 & 89 & 0.892629 \\
24 & 0.99992 & 46 & 0.999271 & 68 & 0.991285 & 90 & 0.88056 \\
25 & 0.999912 & 47 & 0.999199 & 69 & 0.989988 & 91 & 0.867287 \\
26 & 0.999905 & 48 & 0.99909 & 70 & 0.988534 & 92 & 0.852718 \\
27 & 0.999897 & 49 & 0.998962 & 71 & 0.986904 & 93 & 0.836768 \\
28 & 0.999888 & 50 & 0.99882 & 72 & 0.985078 & 94 & 0.81935 \\
29 & 0.999876 & 51 & 0.998665 & 73 & 0.983032 & 95 & 0.800386 \\
30 & 0.999862 & 52 & 0.998499 & 74 & 0.98074 & 96 & 0.779809 \\
31 & 0.999847 & 53 & 1 & 75 & 0.97815 & 97 & 0.757564 \\
32 & 0.999829 & 54 & 0.9998 & 76 & 0.975355 & 98 & 0.733616 \\
33 & 0.999811 & 55 & 0.999574 & 77 & 0.972238 & 99 & 0.707955 \\
34 & 0.999792 & 56 & 0.999285 & 78 & 0.968764 & 100 & 0.680603 \\
35 & 0.999772 & 57 & 0.998912 & 79 & 0.964892 & 101 & 0.651619 \\
36 & 0.999749 & 58 & 0.99848 & 80 & 0.960577 & 102 & 0.621107 \\
37 & 0.99972 & 59 & 0.998073 & 81 & 0.955776 & 103 & 0.589221 \\
38 & 0.999685 & 60 & 0.997616 & 82 & 0.950434 & 104 & 0.556174 \\
39 & 0.999644 & 61 & 0.997107 & 83 & 0.944497 & 105 & 0 \\
\hline
\end{tabular}


The substitution rate of enterprise annuity for female employees is:

$$
R_{\text {female }}=25.0411 \%
$$

Now we exam the effects of starting ages of employees to participate the enterprise annuity plan on substitution rate of enterprise annuity for different genders. We assume that the starting ages can be 28,38 and 48 . The results are summarized in the following table:

Table 8 Genders and the substitution rate of enterprise annuity

\begin{tabular}{|c|c|c|c|c|c|}
\hline \multirow{2}{*}{$\begin{array}{c}\text { The Beginning } \\
\text { Age }\end{array}$} & \multicolumn{2}{|c|}{ Payment Period (year) } & \multicolumn{2}{|c|}{ Substitution Rate of Enterprise Annuity (\%) } & \multirow{2}{*}{$\begin{array}{c}\text { Difference } \\
(\%)\end{array}$} \\
\hline & Male & Female & Male & Female & \\
\hline 18 & 42 & 35 & 27.5422 & 25.0411 & 2.5011 \\
\hline 28 & 32 & 25 & 24.6816 & 21.2499 & 3.4317 \\
\hline 38 & 22 & 15 & 20.2486 & 15.3769 & 4.8717 \\
\hline 48 & 12 & 5 & 13.3865 & 6.28 & 7.1065 \\
\hline
\end{tabular}

From the results in Table 8, we may draw the following conclusions: First, when male and female employees take part in the enterprise annuity plan simultaneously, the substitution rates of enterprise annuity for male employees are always higher than that for female employees whenever they enter the plan, which implies the defects in the current enterprise annuity system in China. Second, with the starting age of entering the enterprise annuity plans more backward, the substitution rates of enterprise annuity decline for both male and female employees, which is consistent with conclusions of the empirical model in previous section.

Third, through the comparison of the substitution rate of enterprise annuity between different genders, we can find out that with the deference of joining in the pension plan, the difference of substitution rate of enterprise annuity between different genders becomes larger, indicating that when female employees join the plan late, the substitution rate of enterprise annuity for them will be greatly reduced.

The analysis above shows that the enterprise annuity system in China has the unfair treatment of sex distinction. The main reason is that retirement age for female employees is far less than that for the male employees, which directly affects the value of substitution rate of enterprise annuity. In addition, in practical life, it is extremely unlikely for female employees to work until retirement without disruption, which will further reduce the level of their wage substitution rate. To deal with this unfairness, protecting living standard of retired women and establishing a fair system of enterprise annuity, there are several suggestions:

1. Moderately delay the retirement age of women workers.

Retirement age $r$ is proportional to $R$, which will increase correspondingly with the increase of $r$. Since the Reform and Opening Policy, life expectancy showed a substantial upward trend. According to the detailed calculation of aggregated data in the sixth national census, in 2010, the average life expectancy of the Chinese population has reached 74.83, which has increased by 3.43 years compared with ten years ago. In order to make the elderly lead a comfortable life, it is necessary to appropriately delay the retirement age for female workers; however, a series of social problems may also appear if they retire too late. 
2. National policies should be enacted as soon as possible.

In western countries, there are countries that convert the time into labor time that female workers spend on maternity, housework and cultivating children. As a result, the substitution rate of enterprise annuity for female workers will be promoted. Although this policy is difficult to implement in current China, government could introduce policies that can reduce the management expense ratio of female workers annuity accounts, which will greatly enhance the value of $R$.

3. The country slightly support the basic pensions of female workers so that their integrated substitution rate of basic pension and enterprise annuity as a whole will be equal to men's.

Specifically, the basic old-age insurance and enterprise annuity are the main sources of individuals' social security after retirement. Although the substitution rates of enterprise annuity female workers under the same conditions are lower than that of male workers, their integrated substitution rate will be improved through enhancing their substitution rate of basic pensions, thus, female employees living standard after retirement will be effectively protected.

\section{Conclusion}

In this paper, we discuss the substitution rate of enterprise annuity under the management costs and expenses of enterprise annuity, and make the sensitivity analysis of each parameter. We figure out the substitution rates of enterprise annuity for different genders. The main results can be concluded as follows:

1. The empirical research and sensitivity analysis of each parameter show that the growth rate of workers' annual income $g$ and the cost rate $f$ are inversely proportional to $R$ and the contribution rate $C$ and the yield $i$ are proportional to $R$. Among the four parameters, the substitution rate of enterprise annuity $R$ is the most sensitive to $i$, with one percent increase in $i, R$ increasing at least 6 points. The substitution rate of the enterprise annuity $R$ is the least sensitive to $f$, with one percent increase in $f, R$ only decreasing by $0.2718 \%$. But it can not be concluded that the management costs and expenses of enterprise annuity should be ignored. Any solution that can insure the living standard of retired workers should be encouraged such as decreasing the proportion of $f$. By sensitivity analysis, the effective method to promote the substitution rate of enterprise annuity is to properly and effectively manage the enterprise annuity, and thus to increase the yield of enterprise annuity fund. Meanwhile, a developed and perfect capital market is indispensable to enhance the investment yield.

2. When women and men participate the enterprise annuity plan at the same age, the substitution rate of men are always higher than that of women. With the delaying of beginning age, the substitution rates of both men and women show downward trends; besides, the differences of substitution rate of enterprise annuity between different genders widens, which indicates that the later the female workers enter the enterprise annuity plan, the smaller their substitution

rate of the enterprise annuity. The remedial measures should be taken to insure the fairness of pension system and eliminate the gender discrimination in the enterprise annuity system.

Acknowledgements We thank the referees for their time and comments. 


\section{References}

[1] Samuelson P A. An exact consumption-loan model of interest with or without the social contrivance of money. The Journal of Political Economy, 1958, 66(6): 467-482.

[2] Diamond P A. National debt in a neoclassical growth model. American Economic Review, 1965, 55: 11261150 .

[3] Diamond P A, Mirrlees J A. A model of social insurance with variable retirement. Journal of Public Economics, Elsevier, 1978, 10(3): 295-336.

[4] Leimer D R, Lesnoy S D. Social security and private saving: New time-series evidence. Journal of Political Economy, 1982: 606-629.

[5] Blanchard O J, Fisher S. Lectures on macroeconomics. The MIT Press, March 21, 1989.

[6] Spivak. The pension crisis in Israel: A conceptual framework and possible solutions. The Economic Quarterly, 1994, 41(3): 484-523.

[7] Gruber J, Wise D A. Social security programs and retirement around the world: Fiscal implications of reform. The University of Chicago Press, 2007: 392.

[8] Rowthorn R E, Ramaswamy R. Deindustrialization: Causes and implications. IMF Working Paper, 1997.

[9] Peskin M W. Asset allocation and funding policy for corporate-sponsored defined-benefit pension plans. The Journal of Portfolio Management, 1997, 23(2): 66-73.

[10] Blake D. Pension schemes as options on pension fund assets: Implications for pension fund management. Insurance: Mathematics and Economics, Elsevier, 1998, 23(3): 263-286.

[11] Dutresne D. Stability of pension systems when rates of return are random. Insurance: Mathematics and Economics, 1989(8): 71-76.

[12] Haberman S. Optimal investment strategy for defined contribution pension scheme. Insurance: Mathematics and Economics, 2001(28): 233-262.

[13] Immergut E M, Anderson K M, Schulze I. The handbook of West European pension politics. Oxford University Press, 2009.

[14] Ebenstein A, Leung S. Son preference and access to social insurance: Evidence from China's rural pension program. Population and Development Review, 2010, 36(1): 47-70.

[15] Bohl M T, Lischewski J, Voronkova S. Pension funds' performance in strongly regulated industries in central Europe: Evidence from Poland and Hungary. Emerging Markets Finance \& Trade, 2011, 47: 80-94.

[16] Stephens M, Unayama T. The consumption response to seasonal income: Evidence from Japanese public pension benefits. American Economic Journal: Applied Economics, 2011, 3(4): 86-118.

[17] Bikker J A, Steenbeek O W, Torracchi F. The impact of scale, complexity, and service quality on the administrative costs of pension funds: A cross-country comparison. The Journal of Risk and Insurance, 2012, 79(2): 477-514.

[18] Woods C, Urwin R. Putting sustainable investing into practice: A governance framework for pension funds. Journal of Business Ethics, 2010, 92(Suppl 1): 1-19.

[19] Shivdasani A, Stefanescu I. How do pensions affect corporate capital structure decisions? The Review of Financial Studies, 2010, 23(3): 1287-1323.

[20] Cocco J F, Lopes P. Defined benefit or defined contribution? A study of pension choices. The Journal of Risk and Insurance, 2011, 78(4): 931-960.

[21] Campbell J L, Dhaliwal D S, Schwartz W C. Financing constraints and the cost of capital: Evidence from the funding of corporate pension plans. The Review of Financial Studies, 2012, 25(3): 868-912.

[22] Bikker J A, Broeders D W G A, Hollanders D A, et al. Pension funds' asset allocation and participant age: A test of the life-cycle model. The Journal of Risk and Insurance, 2012, 79(3): 595-618.

[23] Philip D E, Leo D H. Pension fund finance and sponsoring companies. Journal of Pension Economics and Finance, Cambridge University Press, 2012, 11(3): 439-463. 